NBER WORKING PAPER SERIES

\title{
THE EFFECT OF U.S. SUPREME COURT \\ RULING SULLIVAN V. ZEBLEY ON \\ CHILD SSI AND AFDC ENROLLMENT
}

A. Bowen Garrett

Sherry Glied

Working Paper 6125

\author{
NATIONAL BUREAU OF ECONOMIC RESEARCH \\ 1050 Massachusetts Avenue \\ Cambridge, MA 02138 \\ August 1997
}

Preparation of this paper was assisted by a grant from the Robert Wood Johnson Foundation, Princeton, New Jersey. We would like to thank participants of the NBER Conference on the WellBeing of Children for many useful comments. We thank Kumi Ebihara for helpful research assistance. This paper is part of NBER's research programs in Health Care and Health Economics. Any opinions expressed are those of the authors and not those of the National Bureau of Economic Research.

(C) 1997 by A. Bowen Garrett and Sherry Glied. All rights reserved. Short sections of text, not to exceed two paragraphs, may be quoted without explicit permission provided that full credit, including $(\mathbb{O}$ notice, is given to the source. 
The Effect of U.S. Supreme Court Ruling Sullivan

v. Zebley on Child SSI and AFDC Enrollment

A. Bowen Garrett and Sherry Glied

NBER Working Paper No. 6125

August 1997

JEL No. I18

Health Care and Health Economics

\section{ABSTRACT}

In 1990, in the case of Sullivan v. Zebley, the U.S. Supreme Court substantially relaxed the criteria whereby children became eligible for Supplemental Security Income (SSI) benefits. Since the ruling took effect, the number of children covered by SSI has almost tripled. Currently, nearly 1 million American children are receiving cash and medical benefits through SSI. Many of those newly enrolling in SSI were not previously eligible for cash and Medicaid benefits. Other new eligibles had already been receiving cash and Medicaid through AFDC.

This paper examines the extent of spillovers between the SSI and AFDC programs using the Sullivan v. Zebley expansion in child SSI enrollment to identify spillovers between the programs. We describe how a family's decision to participate in AFDC or SSI is likely to depend on the level of AFDC and SSI supplementation payments in a state. If the likelihood of SSI participation increases with the net financial gain of SSI relative to AFDC, child SSI participation over the period affected by Zebley is likely to be highest in states with low AFDC payments and high state SSI supplementation payments. Using difference-in-difference estimates based on state-level data on program participation and characteristics, we find that the increase in child SSI participation was significantly larger in low-AFDC states than in high-AFDC states. For SSI adults (a group unaffected by the Zebley decision), we find no effect of state AFDC payments on the increase in SSI participation over this period.

We use state-level data pre- and post-Zebley decision to obtain state fixed-effects estimates of the effects of the Zebley decision on SSI participation, AFDC participation, and total program participation. We find that Zebley increased SSI participation and total program participation by children. We find that Zebley increased child SSI participation more in states with lower AFDC payments and higher state SSI supplementation payments. These results suggest that families decide to participate in SSI on the basis of the net financial gain of SSI participation relative to AFDC participation. We attribute $43 \%$ of the Zebley increase in SSI to the SSI-AFDC benefit gap. We examine the effect of Zebley on the federal composition of child cash benefits. While the federal composition increased overall, it increased the least for states in the highest quintile of AFDC payments. We find that Zebley led to a decline in the employment rates of women with a high school education or less, and that this decrease was larger in states with higher AFDC payments.

A. Bowen Garrett

RWJF Scholars in Health Policy Research Program

School of Public Health

140 Warren Hall

University of California, Berkeley

Berkeley, CA 94720-7360

bgarrett@socrates.berkeley.edu
Sherry Glied

School of Public Health

Division of Health Policy

and Management

Columbia University

600 West 168th Street, Room 617L

New York, NY 10032

and NBER

sag1@columbia.edu 


\section{Introduction}

The Supplemental Security Income (SSI) program is a federally administered program that provides cash benefits and Medicaid eligibility to needy aged, blind, and disabled persons. In 1991, the Social Security Administration (SSA) issued new rules that expanded the population of children eligible for Supplemental Security Income (SSI) benefits. These new requirements were issued after the U.S. Supreme Court found the SSA errant in not determining the SSI eligibility of children in the same manner as adults in the February 1990 ruling in Sullivan v. Zebley. ${ }^{1}$ Since the ruling took effect, the number of children covered by SSI has almost tripled. Currently, ${ }^{2}$ nearly 1 million American children are receiving cash and medical benefits through SSI, up from around 340,000 at the end of 1990.

This sizable increase draws from two possible sources. First, many children previously ineligible for cash or Medicaid benefits may now be eligible for benefits through SSI. Second, children already receiving cash and Medicaid eligibility through other entitlement programs such as Aid to Families with Dependent Children (AFDC) may contribute to the growth in SSI. The relative share of these two sources has important policy implications. The extent to which children are transferring from AFDC to $\mathrm{SSI}^{3}$ determines the importance of SSI to its new beneficiaries and the true (net) budgetary cost of the SSI expansion. Recent welfare legislation

\footnotetext{
${ }^{1}$ Sullivan v. Zebley, 1990, 493 U.S. 521.

2 992,140 children were receiving SSI benefits in February 1996 (SSA, current operating statistics).

${ }^{3}$ Conceptually, we include those children who would have become AFDC recipients in the absence of the new SSI eligibility rules.
} 
changed SSI eligibility rules back to their original (pre-Zebley) form. ${ }^{4}$

This paper examines the extent of spillovers between the SSI and AFDC programs using state-level data on program participation and characteristics. The Sullivan v. Zebley decision provides a means of identifying such spillover effects. Because this change in SSI policy was imposed on the SSA by the U.S. Supreme Court rather than by political pressures on Congress or the executive branch, the expansion of SSI eligibility can be usefully viewed as an exogenous policy shock. We examine how child SSI enrollment, AFDC enrollment, and total program enrollment changed because of the Sullivan $v$. Zebley decision and how these changes varied with state differences in SSI and AFDC payment levels.

The Zebley expansion in child SSI participation is likely to have important effects on the employment of its participants. The expansion in SSI should lead to a decline in the employment of the parents of children who had not been eligible for cash benefits through AFDC. For AFDC participants who switch to SSI, the effect on employment is unclear. The SSI program treats earned income more generously than the AFDC program. Beyond some level of income, each additional dollar of earned income is offset by a $\$ 0.50$ reduction in benefits, producing a marginal tax rate on earned income of 50\%. In the AFDC program, each additional dollar of earned income is offset by a one dollar reduction in AFDC benefits, producing a marginal tax rate on income of $100 \% .^{5}$ If a child switches to SSI and other family members continue to receive AFDC, we expect work disincentives to increase. If a child switches to SSI and the family no longer receives AFDC, work disincentives could decrease. In the empirical analyses

\footnotetext{
${ }^{4}$ see Personal Responsibility and Work Opportunity Reconciliation Act of 1996, H.R. 3734.

${ }^{5}$ The AFDC tax rate is $66 \%$ for the first four months of work.
} 
below, we examine the effect of the Zebley decision on the employment rates of low income women.

\section{The Supplemental Security Income program}

The Supplemental Security Income program is a means-tested, federally administered program that provides monthly cash assistance payments to needy aged, blind, and disabled persons. ${ }^{6}$ Currently, the monthly federal benefit standard is $\$ 470$ for individuals and $\$ 705$ for couples. In order to qualify for SSI payments, an individual must satisfy the program criteria for age, disability, or blindness, have limited income and resources, and be a U.S. citizen or a legal immigrant of permanent residence status. The SSA defines disabled individuals as those who are "unable to engage in any substantial gainful activity by reason of a medically determined physical or mental impairment expected to result in death or that has lasted, or can be expected to last, for a continuous period of at least 12 months." At their option, states may supplement the federal payment. States may chose to supplement the SSI payment for certain participants and not for others.

Eligibility and the SSI benefit level are determined by an individual's countable income. ${ }^{7}$

To compute countable income, certain exclusions are made for earned and unearned income. In

the case of a child, some portion of the income of the parents is considered to belong to the child (deemed to the child), taking into account the needs of non-SSI eligible family members (discussed in more detail in the Appendix). Public maintenance payments, such as AFDC, are

\footnotetext{
${ }^{6}$ Except where noted, the program information contained in this section is from the Overview of Entitlement Programs, U.S. Congress, House Committee on Ways and Means (hereafter, Green Book).

${ }^{7}$ In addition to these limitations, there are other limitations on unearned income and total resources (assets). Many types of in-kind income (particularly medically related in-kind income) may be excluded from countable income.
} 
excluded from SSI countable income. In addition, all income considered countable in the determination of public maintenance payments is excluded from SSI countable income. An individual cannot receive both SSI and AFDC benefits, and can choose either program, given eligibility in both programs. A family with more than one child can have a child in both programs. AFDC agencies generally encourage individuals to apply for SSI.

In most states, including the District of Columbia, Medicaid eligibility is automatic with SSI eligibility. In seven states, SSI recipients must complete a separate application with the state agency which administers the Medicaid program. ${ }^{8}$ Twelve states impose Medicaid Eligibility criteria that are more restrictive than SSI criteria. In these states, referred to as "209(b)" states, states may be more restrictive with respect to their definitions of blindness or disability and/or their financial requirements for eligibility, and may require a separate application. ${ }^{9}$

\section{The Supreme Court's decision in Sullivan v. Zebley}

On February 20, 1990, the United States Supreme Court ruled in Sullivan v. Zebley that the Social Security Administration was improperly determining the eligibility of children for SSI. Before 1990, both adults and children were eligible for SSI benefits if they had a condition appearing on a list of impairments maintained by the SSA. Failing this, adult applicants were given an individual functional analysis (IFA) to determine disability. Child applicants did not receive this analysis and were determined ineligible if they did not meet a listed condition. On February 11, 1991, the SSA published revised regulations for determining disability in children.

\footnotetext{
${ }^{8}$ These states are Alaska, Idaho, Kansas, Nebraska, Nevada, Oregon, and Utah.

${ }^{9}$ The "203(b)" states are Connecticut, Hawaii, Illinois, Indiana, Minnesota, Missouri, New Hampshire, North Carolina, North Dakota, Ohio, Oklahoma, and Virginia.
} 
Under the new regulations, children receive individual functional analyses and are considered disabled if they have an impairment of comparable severity to that of an adult. In practice, children who are unable to function in an "age-appropriate" manner may be eligible for SSI.

As part of the settlement agreement of the case, the Social Security Administration made efforts to locate child applicants retroactive to January 1,1980 who had been denied benefits. Some 452,000 individuals were sent notices indicating that they might be eligible for SSI. Since then, child enrollment in SSI has increased dramatically. This sharp increase is illustrated in Figure 1, which shows that the SSI population was stable until the time of the Zebley decision and increased thereafter. This increase includes, in part, those of the retroactive class, but it also includes many new applicants.

Two other changes in eligibility SSI for children occurred at the same time as the Zebley. First, some child mental health impairments, such as attention deficit hyperactivity disorder and eating disorders, were added to the list of qualifying disabilities in 1990, in accordance with the Disability Benefits Reform Act (DBRA) passed in 1984. The DBRA also required new mental health functional criteria. New mental health functional criteria were already in place for adults prior to 1990. In 1990, new mental health functional criteria were implemented for children as well. While the Zebley ruling directly applied to medical eligibility criteria, the SSA extended IFA's to mental health eligibility criteria as well after the decision. In our analyses, we examine the combined effect of these changes in 1990, referring to them collectively as the Zebley changes.

Second, in 1992, the SSA changed the way in which parental earnings were counted as income (i.e. deemed to children). Hannsgen and Sandell (1996) describe this change in deeming 
rules and find that its more generous treatment of earned income resulted in a two percent increase in the number of children on the SSI roles and increased payments for 4.4 percent of children under 18 on SSI.

Extending SSI benefits to children with impairments who do not necessarily meet a listed disorder may improve the living conditions of and provide access to insurance coverage to a significant group of children. Requiring children to meet a listed condition in order to quality for SSI, as was required before Sullivan v. Zebley, effectively denied benefits to many children (especially those with mental health impairments) whose conditions were not easily diagnosed. More of these children became eligible for benefits as a result of the Sullivan v. Zebley decision through individual functional assessments. These children are disproportionately located among the poor and children in single-parent households (Glied et al., 1997).

\section{Changes in the characteristics of child SSI participants}

The characteristics of child SSI recipients have changed in the years since the Zebley decision. A larger share of the SSI population is classified as having mental disorders, particularly psychotic and neurotic conditions. Between 1989 and 1992, the share of SSI children receiving payments due to a psychotic or neurotic disorder increased from 6.4 percent to 16.6 percent (Kennedy, 1993).

The living arrangements of SSI children have also changed since the Zebley ruling. The share of children living with their parents rather than with no parents (institutional, foster care) has increased from 77.1 percent in 1989 to 83.4 percent in 1992. The share of children living with both parents increased somewhat, but the largest increase is from children living in singleparent families. This group increased from 47.2 percent of SSI children in 1989 to 52.3 in 1992. 
In this respect, children in the SSI program are becoming more like children in the AFDC program.

\section{Incentive effects of Sullivan v. Zebley on SSI and AFDC participation}

In order to analyze the effects of changes in state SSI supplementation payments and maximum AFDC payments on an individual's choice to participate in SSI or AFDC before and after the Zebley decision, it is necessary to look at how eligibility and payments are determined in the two programs. The appendix describes the eligibility rules and procedures used to compute the payment in the SSI and AFDC programs. From these rules, it follows that the SSI payment level $(W)$ depends on an eligible individual's income $(x)$ and the level of the state SSI supplementation payment $(S)$ :

$$
W=W(x, S), \delta W / \delta x \leq 0, \delta W / \delta S>0 \text {. }
$$

Similarly, the AFDC payment level $(V)$ for an eligible individual depends on the individual's income $(x)$ and the AFDC maximum grant $(M)$ in the state:

$$
V=V(x, M), \delta V / \delta x \leq 0, \delta V / \delta M>0 .
$$

The level of income at which SSI eligibility ends (and the payment is equal to zero) is an increasing function of state SSI supplementation payments. We denote this SSI cutoff point as (s) ${ }^{10}$ Similarly, the point where AFDC eligibility ends is an increasing function of the AFDC maximum grant. We denote the AFDC cutoff point as $(m)$. Symbolically,

\footnotetext{
${ }^{10}$ Currently, a single-parent family with one SSI-eligible child and one ineligible child would be eligible for an SSI payment if the parent had earned income up to $\$ 2,240$. A two-parent family with one eligible child and one ineligible child would be eligible for a payment if the parents jointly earned less than $\$ 2,710$. This assumes all income is earned and no state SSI supplementation (Source: Social Security Administration. SSI Deeming BreakEven Chart-1996).
} 
$s: W(s, S)=0, s=s(S), \frac{d s}{d S}>0 ; m: V(m, M)=0, m=m(M), \frac{d m}{d M}>0$

The analysis below focuses on the population of children who would be eligible for AFDC payments if the family met income eligibility requirements for AFDC. Children living in households with a single mother are eligible for AFDC benefits subject to income eligibility requirements. Children in two-parent families may also be eligible for payments through AFDCUP (AFDC Unemployed Parent program). ${ }^{11}$ Fewer than $10 \%$ of child AFDC recipients are eligible through AFDC-UP.

For notational simplicity we assume that individuals have no unearned income except that which may come from AFDC or SSI, and that individuals do not respond to different payment levels by adjusting the amount of time that they work. ${ }^{12}$ The distribution of income $x$ in state $k$ in year $t$ is given by the cumulative density function $F_{k, t}(x)$ and the probability density function $f_{k, t}(x)$.

We assume that all children are equally likely to meet SSI criteria for a medical or mental impairment, with some fixed probability $\left(\rho_{t}\right)$ that increased as a result of the Sullivan v. Zebley decision. We define $\rho_{t}$ as follows:

$$
\rho_{t}=\left\{\begin{array}{l}
\rho_{0} \text { if } t<1990,0<\rho_{0}<1 \\
\rho_{1} \text { if } t>1990, \rho_{0}<\rho_{1}<1 .
\end{array}\right.
$$

This reflects the increase in the fraction of children who met impairment criteria for SSI benefits in the post-Zebley period. If demonstrating SSI impairment criteria is costless (an

\footnotetext{
"As of October 1, 1990, all states are required to offer AFDC to children in two-parent families who are needy because the principle wage earner is unemployed, subject to the wage earner having a history of work. Participation in AFDC-UP is limited to 6 months in states that did not have AFDC-UP programs prior to October $1,1990$.

${ }^{12}$ We examine the effect of payment levels on female employment in section 6.
} 
assumption we relax below) individuals will participate in SSI if they meet both SSI impairment criteria and SSI income eligibility criteria. We assume that children will participate in AFDC if they meet AFDC income eligibility criteria and are not also eligible for SSI (because the cash benefits for SSI are larger). The fraction of children in state $k$ who would participate in SSI in year $t$ is given by

$$
p_{S S I, k, t}=F_{k, t}\left(s_{k, t}\right) \cdot \rho_{t} .
$$

Similarly for AFDC,

$$
\bar{p}_{A F D C, k, t}=F_{k, t}\left(m_{k, t}\right) \cdot\left(1-\rho_{t}\right) .
$$

In states with higher state SSI supplementation payments, more children would meet income eligibility requirements for SSI. Changes in SSI eligibility will cause increases in $p_{S S I, k, t}$ proportional to $F_{k, t}\left(s_{k, t}\right)$. The growth of SSI following the relaxation of eligibility requirements would be higher in states with higher SSI supplementation payments. In this model, when SSI eligibility requirements are relaxed $\left(\rho_{t}\right.$ is increased), the proportion of new SSI cases coming from prior $\mathrm{AFDC}$ cases is equal to

$$
F_{k, t}\left(m_{k, t}\right) / F_{k, t}\left(s_{k, t}\right) .
$$

While the relative share of SSI growth within a state coming from AFDC will depend on the maximum AFDC payment, an important result is that the total growth in SSI does not depend on the maximum AFDC payment, but only on the level of state SSI supplementation. This is a direct result of the assumption that demonstrating SSI impairment criteria is costless. We summarize these effects in the first row of Table 1.

Economic theory suggests that costs of eligibility, including stigma, time, and 
information costs, might reduce the take-up rate for SSI. For example, parental effort may be required in marshaling evidence of the child's disability from a variety of sources that are considered. These include medical records (describing symptoms, signs, or laboratory findings), information on day-to-day functioning (from parents, other caretakers, other family members, and teachers), and documentary evidence from school or intervention programs (often in the form of evaluation instruments). Anecdotal evidence suggests that parents do indeed make efforts in producing "source evidence" to get their children qualified for SSI that include obtaining forms from school teachers documenting behavioral problems and getting their children enrolled in special education programs. SSI does not reimburse the expenses that parents incur in demonstrating eligibility. In cases in which medical evidence is lacking, however, the state disability determination service arranges a consultative examination by a physician to obtain medical evidence at the SSA's expense (SSA, 1995).

The presence of such costs suggests a two-step process in which parents take efforts to demonstrate a child's impairment (taking into account the benefits and costs of obtaining this determination), and then a determination of eligibility is made with probability $\rho_{t}$.

If an AFDC eligible child is moved from AFDC to SSI, the family would lose the portion of the family's AFDC payment that is allocated to the child, while gaining the federal SSI benefit and the state SSI supplementation payment. The benefits of SSI participation relative to AFDC participation for a child decreases with the child's portion of the family's AFDC grant and increases with the state SSI supplementation payment. The benefit declines with $x$, as payments phase out with income. Assume that the family faces a cost $(c)$ of demonstrating impairment. Then, the likelihood that a child is enrolled in SSI will depend on the net gain obtained from SSI 
participation relative to AFDC participation, and the likelihood that the child meets SSI

impairment criteria $\left(\rho_{t}\right)$. This gain may be large. In 1994, in the five lowest-paying AFDC states

(Mississippi, Alabama, Texas, Tennessee and Louisiana), the average AFDC maximum payment

to a family of three was $\$ 169$. By contrast, the federal SSI benefit for an individual in 1994 was

\$446. Also, while the marginal AFDC payment for an additional child generally declines, the marginal SSI payment for an additional child fixed, and there is no household limit. A family with two SSI-eligible children with no countable income received $2 * \$ 446=\$ 892$ per month in federal benefits in $1994 .^{13}$

We denote the likelihood $(g)$ that an impaired child with income $x$ in state $k$ in year $t$ will participate in SSI as:

$$
g=g\left(S_{k, t}, M_{k, t}, c, x\right)
$$

Under the hypothesis that $g$ increases with the net gain of SSI participation, $g$ increases with $S_{k, t}$ and decreases with $M_{k, t}, c$, and $x$ as suggested by the incentives described above. If there are no costs to obtaining SSI eligibility $(c=0)$, then $g=1$, and we obtain the situation described in equations 5 and 6 . The fraction of children in state $k$ participating in SSI in year $t$ is now expressed as:

$$
p_{S S I, k, t}=\rho_{t}\left[\int_{0}^{m\left(M_{k, t}\right)} g\left(S_{k, t}, M_{k, t}, c, x\right) f(x) d x+\int_{m\left(M_{k, t}\right)}^{\beta\left(S_{k, t}\right)} g\left(S_{k, t}, M_{k, t}, c, x\right) f(x) d x\right]
$$

The first and second terms in brackets represent the AFDC eligible and AFDC ineligible children respectively. The fraction of children participating in AFDC and total program participation (SSI

\footnotetext{
${ }^{13}$ The National Committee on Childhood Disability, in its 1995 report to Congress, recommended adjusting payments for additional SSI-eligible individuals in a household to account for economies of scale in the provision of food, shelter, etc., and recommended a household limit on benefits.
} 
and AFDC combined) are:

$$
\begin{aligned}
& p_{\text {AFDC. } k, t}=F\left(M_{k, t}\right)-\rho_{t} \int_{b}^{m\left(M_{k, t}\right)} g\left(S_{k, t}, M_{k, t}, c, x\right) f(x) d x . \\
& p_{\text {Total, } k, t}=F\left(M_{k, t}\right)+\rho_{t} \int_{m\left(M_{k, t}\right)}^{\left(S_{k, t}\right)} g\left(S_{k, t}, M_{k, t}, c, x\right) f(x) d x .
\end{aligned}
$$

The effect of the Zebley expansion in SSI eligibility on program participation is obtained by taking the derivative of the above quantities with respect to $\rho_{t}$ :

$$
\begin{aligned}
& \delta\left(p_{S S I, k, t}\right) / \delta \rho_{t}=\int_{0}^{m\left(M_{k, t}\right)} g\left(S_{k, t}, M_{k, t}, c, x\right) f(x) d x+\int_{m\left(M_{k, t}\right)}^{\left(\left(S_{k, t}\right)\right.} g\left(S_{k, t}, M_{k, t}, c, x\right) f(x) d x,(12 .) \\
& \delta\left(p_{A F D C, k, t}\right) / \delta \rho_{t}=-\int_{0}^{m\left(M_{k, t}\right)} g\left(S_{k, t}, M_{k, t}, c, x\right) f(x) d x \\
& \delta\left(p_{\text {Total }, k, t}\right) / \delta \rho_{t}=\int_{m\left(M_{k, t}\right)}^{\left(S_{k, t}\right)} g\left(S_{k, t}, M_{k, t}, c, x\right) f(x) d x
\end{aligned}
$$

Equation 12 indicates that child SSI participation will increase more as a result of Zebley in states with low AFDC payments due to the increased incentive to participate in SSI. Child SSI participation will increase more in high SSI supplementation payments because of the increased incentive to participate in SSI and because of the increased limit for income eligibility. The sign of the effect of the maximum AFDC grant on the change in AFDC participation due to Zebley in equation 13 is ambiguous. There will be more potential switchers in high AFDC states, but the incentive to switch will be lower. Child AFDC participation will decline more in states with high SSI supplementation payments. The change in total program participation due to Zebley will be lower in states with high AFDC payments and low SSI supplementation, as suggested by equation 14 . These effects are summarized in the second row of Table 1 .

An alternative hypothesis to the individual incentives to participate in SSI described above is that information about the SSI program drives patterns of SSI participation. Information 
about the SSI program should increase with exposure to AFDC if welfare offices and social workers disseminate information about SSI eligibility. Under this hypothesis, the likelihood of SSI participation, $g=g\left(M_{k, t}\right)$, increases with $M_{k, t}$. Implications for the effects of SSI supplementation payments would be the same as in row 1 of Table 1, but this hypothesis produces different predictions for the effect of AFDC payments on patterns of changes in participation caused by Zebley. High AFDC states would have a larger increase in SSI participation after Zebley. High AFDC states would have a larger decline in AFDC participation. AFDC payments would have an ambiguous effect on total program participation. We summarize the implications of this hypothesis in the third row of Table 1.

States may also have incentives to prefer children to be on SSI rather than AFDC. States share the costs of AFDC programs with the federal government. In states with no state SSI supplementation, the federal government pays the full SSI benefit. The federal matching rate for AFDC programs is related to the economic conditions within a state and varies from year to year. The federal matching rate for AFDC is $50 \%$ in states such as California and New York and increases to $80 \%$ for low-income states such as Mississippi and West Virginia. States who pay a higher share of AFDC costs may be more likely to encourage AFDC recipients to apply for SSI benefits. The GAO estimates that at least half of all states fund programs that actively assist disabled welfare recipients through the SSI application process. They cite the example of five (unnamed) states that have used such programs to generate gross savings of about $\$ 90$ million in a given year by helping enroll nearly 26,000 individuals receiving state benefits in SSI (GAO, 1995). 


\section{Data and estimation strategy}

We use annual state-level data for SSI and AFDC participation published by the Social Security Administration to examine the effect of state characteristics on SSI and AFDC participation. Table 2 describes the data used and their sources. We use the level of AFDC payment to a family of one parent and two children at a point in time as our measure of the AFDC payment to an individual child in a state. This is likely to be a good measure of the generosity of a state's AFDC program, but not a perfect measure, due to state heterogeneity in the payment standard for the marginal child recipient in an AFDC family.

Table 3 presents national summary statistics for 1989 and 1992. Both SSI and AFDC participation increased nationally over this period. Nineteen states had made state supplementation payments to children. In real terms, both the average AFDC payment and the average SSI supplementation payment declined over this period.

We estimate the effects of AFDC program generosity in two ways. First, we obtain difference in difference estimates of how the effect of Zebley on SSI varied between high-AFDC and low-AFDC states. We define high- and low-AFDC states using the 1992 median as the cutoff value. Using this technique, we also show that the effect of a state's AFDC payment on SSI participation is, more likely, due to the Zebley decision than to changes in SSI overall that occurred over the same time period. While SSI eligibility for children with disabilities was affected by the Zebley decision, SSI eligibility for adults should not have been affected by the decision. We repeat the difference in difference analysis for adults.

Second, in a multivariate model using three years of data before and after the Zebley decision, we estimate the effects of the AFDC payment and state SSI supplementation on SSI 
participation, AFDC participation, and total program participation. Each variable is interacted with the dummy variable ZEBLEY, which indicates the post-Zebley period. The main effects of interest are ZEBLEY and the interaction effects, which measure how the effect of Zebley varied by state program characteristics. ${ }^{14}$ We include the state share of AFDC costs and its interaction with ZEBLEY. We interact this variable with ZEBLEY because we expect high-share states to be even more likely to encourage AFDC recipients to take up SSI when the eligibility rules are relaxed. We include a year variable to control for an overall linear trend in program participation. We estimate this model using OLS with state fixed-effects using state-level data from 1987 to 1994 (three years before and three years after the Zebley decision). This sample is chosen to exclude the year of the decision (1990) and the year that the new guidelines were issued by the SSA (1991) so that our estimates are based on years that are fully in the pre- and post-Zebley regimes. ${ }^{15}$ Huber-White robust standard errors, corrected to adjust for sampling error in non-administrative variables from smaller states are reported for the OLS regressions results below. We re-estimate the model, adding in state income per capita and the child poverty rate. We then allow for state-varying time trends in SSI participation in two ways. First, we add separate linear trends to the model for each state. Second, we use the adult SSI rate and the adult SSI rate * ZEBLEY, which controls for state-specific trends in SSI participation pre- and postZebley, while retaining degrees of freedom.

\footnotetext{
${ }^{14}$ AFDC and state SSI supplementation payments contain sufficient within-state variation to estimate the parameters of this model. The overall standard deviation of the maximum AFDC grant is 113 and the within standard deviation is 23 . The overall standard deviation of state SSI supplementation payments is 22 and the within standard deviation is 4.5 .

${ }^{15}$ We re-ran our analyses including the two transitory years, 1990 and 1991 , in our sample but this did not substantively affect our results.
} 


\section{Results for the effect of Sullivan v. Zebley on child SSI and AFDC participation}

Table 4a presents difference-in-difference estimates of the effect of the Zebley decision and state AFDC payment on child participation rates in SSI. SSI increased more in absolute terms in low AFDC states. The difference-in-difference is significant at 5\%, and the magnitude of the effect $(-0.28)$ is large (nearly one-third) relative to the size of the SSI program for children (0.92 in 1992). Table $4 \mathrm{~b}$ performs the same analysis for adults receiving SSI, whose status was not affected by the Zebley decision. Table $4 \mathrm{~b}$ shows that SSI participation for adults did rise somewhat over the Zebley period, but that this increase did not vary by the level of AFDC payment in a state. This effect is in the opposite direction, but is less than one percent of the SSI program size for adults. Increases in adult SSI participation have come largely from increases in adults with mental disabilities or functional limitations and increases in SSI participation by noncitizens (GAO, 1995).

Table 5a presents OLS fixed effects estimates of the effects of state AFDC and SSI program characteristics on the rate of SSI participation, AFDC participation, and total program participation. Column one presents results for SSI participation. ZEBLEY has a significant positive effect on the SSI participation rate even after controlling for several other factors that are hypothesized to affect SSI participation.

The main result of interest is the effect of the maximum AFDC grant after Zebley. The effect of the AFDC maximum grant is significantly more negative after the Zebley decision than before. The magnitude of this effect is such that a $\$ 100$ increase in a state's AFDC payment results in a 0.20 percentage point additional decrease in the child SSI participation rate after 
Zebley. This point estimate is similar to that in the difference-in-difference in Table 4a.

A second interesting result is that the increase in SSI participation post-Zebley is significantly related to the state SSI supplementation payment. The magnitude of this effect is large. A $\$ 100$ increase in state SSI supplementation increases SSI participation by an additional 0.52 percentage points after Zebley. We find that child SSI participation is higher in states that pay a higher share of AFDC program costs, but we find evidence contrary to the hypothesis that these states experienced a larger increase in SSI participation post-Zebley. We find a highly significant negative effect of unemployment on child SSI participation where we would expect to find a positive effect. This result is surprising in the light of findings (Rupp and Stapleton, 1995) that more unemployment increases DI applications and means-tested program participation generally. We unable to explain why SSI for children would be different in this respect. We note, however, that our main results for the effects of AFDC and SSI payments on child SSI do not differ if we exclude unemployment from our regressions. We repeated this analysis with SSI adults as the dependent variable (not reported). We find that Zebley did not have an effect on adult SSI participation.

Column two reports results for AFDC participation rates. Results for the ZEBLEY variable suggest that Zebley did not lead to a significant decline in AFDC participation after controlling for other variables. Child AFDC participation rates increased sharply over this period, from $9.7 \%$ in 1989 to $11.8 \%$ in 1992 . Although we would expect Zebley to decrease AFDC participation, the estimated coefficient on ZEBLEY is positive, suggesting that our model does not fully account for the increase in AFDC participation over this period. The effect of the AFDC maximum grant is positive as expected and significant. We find no change in this effect 
post-Zebley. The effect of state SSI supplementation on AFDC is more negative after Zebley, but the difference is not significant. Coefficients for the unemployment rate, poverty rate, and income per capita are in the expected directions and significant.

Column three looks at the sum of SSI and AFDC participation for children. Results for the ZEBLEY indicate that growth in SSI did contribute to total program growth. We estimate that the effect of the AFDC maximum grant is significantly less positive post-Zebley (at the $10 \%$ level), indicating that total program participation increased less in states with higher AFDC payments.

We add state-specific linear trends to the model and report results for the re-estimated model in Table 5b. Our main result that SSI increases less in states with higher AFDC payments after Zebley continues to hold, although the magnitude of this effect is reduced by about half (0.0012). Our results for the effect of state SSI supplementation on child SSI participation is no longer significant, and the baseline effect of SSI supplementation is negative. The effect of Zebley does not change with the state's AFDC share. For the AFDC participation rate in column two, the baseline AFDC effect loses significance when we add state-specific trends. The change in this effect due to Zebley changes sign but remains insignificant. In column three, the effect of the AFDC maximum grant on total program participation is negative but loses significance. We repeated this analysis with both linear state trends and quadratic state trends. We do not report these results since relatively few degrees of freedom remain to estimate the parameters of interest. We note, however, that our main result that SSI increases less in states with higher AFDC payments and more in states with higher SSI supplementation payments after Zebley holds. The magnitude of the AFDC maximum grant * ZEBLEY coefficient is somewhat reduced 
$(-0.0006)$, and the result remains statistically significant with a t-statistic of 3.6.

In Table 5c, we add the adult SSI participation rate to our regressions to control for overall changes in the SSI program. We allow the relationship between adult and child SSI to vary over the period by interacting the adult SSI participation rate with the ZEBLEY. Adult SSI participation increased over the Zebley period. In column one, the Adult SSI participation rate * ZEBLEY variable picks up the increase in child SSI participation. The effect of the AFDC maximum grant is similar to the results above. The magnitude of this effect $(-0.0011)$ is similar to the effect we obtain when we include the state-specific trends. The magnitude of the Zebley change in the effect of state SSI supplementation is reduced (0.0014) and is no longer significant. The effect of the state AFDC share is more positive post-Zebley, but the increase in the effect of the AFDC share is not significant. Results for AFDC in column two are similar to our base results. Results for total program participation in column three are also similar to our base results, but the reduction in the effect the AFDC maximum grant post-Zebley is not significant.

Our primary result that child SSI participation increased less post-Zebley in states with higher AFDC payments is consistent with the hypothesis that there is a cost involved in becoming eligible for SSI and the decision to participate in SSI involves a comparison of these costs with the benefits of SSI participation relative to AFDC. Other effects implied by this hypothesis in Table 1 are largely consistent with our empirical results. Our findings rule out the other hypotheses we consider in Table 1.

In order to summarize the magnitude of the effect of AFDC payments on the Zebley increase in SSI participation, we use the regression results in Table $5 \mathrm{c}$ to simulate the average increase in child SSI participation at the 1992 median level of the AFDC maximum grant (\$262) 
and at the 90th percentile of the AFDC maximum grant. Using the 90th percentile AFDC maximum grant, we measure the baseline increase in SSI where the gap between SSI and AFDC benefits is near the lowest obtained in practice. ${ }^{16}$ At the median maximum AFDC grant, we predict child SSI participation would increase by 0.65 percentage points. If every state had the 90th percentile AFDC maximum grant, child SSI participation would increase by 0.37 percentage points. From this we conclude that at the median level of the AFDC grant, an estimated $43 \%$ of the increase in SSI is attributable to incentives resulting from the SSI-AFDC benefit gap.

These results also indicate that program switching incentives do not completely explain the Zebley increase in child SSI participation. For families who did not initially qualify for benefits through AFDC, the relaxation of eligibility requirements resulting from Sullivan $v$. Zebley leads to a real increase in program coverage. This population is likely to consist largely of children in two-parent households, and single-parent households in which the parent's earnings disqualify the family for AFDC benefits.

The fixed federal SSI benefit and the finding that SSI increased more in states with low AFDC payments suggests that Sullivan $v$. Zebley resulted in an increase in federal money going to states with low AFDC payments at the expense of states with high AFDC payments. Table 6 examines estimates of total and federal spending on children from both the AFDC programs and SSI programs before and after the Zebley decision by quintile of the AFDC maximum grant. Total monthly AFDC payments to children were computed as one half of the AFDC maximum

\footnotetext{
${ }^{16}$ Even in the highest paying AFDC states, the net gain in payments of moving a child from AFDC to SSI is positive. If the net gain is positive, after accounting for costs of obtaining SSI eligibility, this estimate is an overestimate of the baseline increase in SSI in the absence of incentive effects.
} 
grant to a family of one adult and two children multiplied by the number of child AFDC participants in a state. The federally-financed share of this amount was computed by multiplying the amount by the applicable federal matching rate for AFDC in the state. Federal monthly SSI payments to children were estimated as the SSI federal benefit rate multiplied by the number of child SSI participants. Total monthly SSI payments to children were obtained by adding the state supplementation payments multiplied by the number of SSI children in the state.

Results in Table 6 indicate that the federal share of total payments to children increased between 1989 (before Zebley) and 1992 (after Zebley) for all quintiles of the AFDC payment. States with the highest AFDC payments, however, had the smallest increase in the federal share over the period. States making lower AFDC payments, who typically already spend a lower share for AFDC, and who experienced larger increases in SSI, had larger increases in the federal share of total payments to children over this period. This effect does not appear to be monotonic, most likely due to the fact that in states with the smallest AFDC payments, the federal share of AFDC payments is already large so that the percent change in federal financing of payments to children over the period declines after some level. Relative to states with the highest AFDC payments, the Zebley decision appears to have had an important effect on the financing of payments to children that favored states making lower AFDC payments.

\section{The effect of Sullivan v. Zebley on female employment}

Both SSI and AFDC provide income to families and tax it as income increases, and as a result, both programs reduce the incentive to work. Ceteris paribus, an expansion in SSI should lead to a decline in employment among those newly eligible. For AFDC families containing a child who switches to SSI, the incentives to work will increase or decrease, depending on 
whether other members of the family remain eligible for AFDC. Work disincentives are smaller under SSI than AFDC alone, but if family members remain on AFDC, parents may lose income from both programs for every dollar of earned income. We examine the effect Zebley on female employment using state-level employment data and a similar specification as above.

- Because the SSI program for children is small relative to the overall population, we narrow the focus of this analysis to women likely to be eligible for SSI benefits: non-student unmarried women between the ages of 16 and 45 with a high school education or less. We compute these rates by year, by state, using monthly data from the Current Population Survey.

Table 7 reports the results of state fixed-effects regressions of state employment rates on a linear trend, the Zebley indicator, the maximum AFDC grant and state SSI supplementation payments, and their interactions with Zebley. We exclude the unemployment rate, poverty rate, and per-capita income from these analyses due to their codetermining relationship with female employment. We exclude the state share of AFDC payments from this analysis because of the lack of a strong theoretical relationship with female employment. In column one, we find that Zebley had a negative effect on female employment. The effect of Zebley is significantly more negative in states with higher AFDC payments. This result suggests that high AFDC-states, while experiencing smaller increases in child SSI, nonetheless experienced a larger increase in the number of children in families receiving both SSI and AFDC simultaneously. We find Zebley led to a larger decrease in employment in states with higher SSI supplementation payments, although this effect is not significant. The sign of this effect is consistent with our expectations, as our findings above suggest that these states had larger increases in newly eligible children. 
The male unemployment rate is added to the regression in column two in order to control for general economic conditions. These results are similar to the results obtained in column one. The result for the post-Zebley maximum AFDC grant variable is reduced by the inclusion of the male unemployment rate, but remains significant at $5 \%$.

\section{Conclusions}

The Supreme Court decision Sullivan v. Zebley greatly increased the number of children receiving SSI benefits, and the number of children receiving cash benefits overall, by allowing children to qualify for SSI benefits through individual functional assessments. Zebley had a larger effect on child SSI participation in states with lower AFDC payments and states who supplement the federal SSI payment. These findings suggest that families decide to participate in SSI on the basis of the net financial gain of SSI participation relative to AFDC participation. We estimate that $43 \%$ of the Zebley increase in SSI is attributable to the SSI-AFDC benefit gap.

One implication of this pattern of growth in child SSI participation is that the federal composition of child cash benefits increased over this period, but increased the least for states with the highest level of AFDC payments. More broadly, our results illustrate how programs may interact when they serve similar populations. Finally, we find that the Zebley expansion in SSI benefits led to a decrease in the employment rates of women with a high school education or less. This decline in employment was greater in states with higher AFDC payments, suggesting a larger increase in the number of families enrolled in both AFDC and SSI in these states. 


\section{Appendix}

\section{Eligibility and payment determination in the SSI program}

The first step in determining whether a child is eligible for an SSI payment given that the child meets disability criteria is to determine the child's countable income. In deeming income from an ineligible parent to an SSI eligible child, the SSA determines the current monthly earned and unearned income of the parents. ${ }^{17}$ From this amount, allocations for each ineligible child are deducted. In 1992, the allocation for each ineligible child was $\$ 211$. Next, allocations from the parent(s) are deducted. No allocation is made for a parent who is receiving public incomemaintenance payments such as AFDC. To compute their allocation, $\$ 20$ is deducted from unearned income or from earned income if unearned income is less than $\$ 20$. Next, $\$ 65$ plus one-half of the remainder of earned income is deducted. From the remainder, the monthly federal SSI benefit rate for a couple is subtracted if the child lives with both parents. The federal monthly benefit rate for an individual is subtracted if the child lives with one parent. Any of the parents' current monthly income that remains is deemed to the child. ${ }^{18}$ The result is the child's unearned income. $\$ 20$ is deducted to obtain the child's countable income.

Given the child's countable income, a child is eligible for SSI benefits and will receive a payment if the federal SSI benefit plus the state SSI supplementation benefit (if any) is greater

\footnotetext{
${ }^{17}$ Information on Social Security Administration income deeming procedure is contained in CFR $\S 416.1160$ 416.1169. Many details of income determination, exclusions, and deeming are suppressed in order to focus on the features most essential to this analysis.

${ }^{18}$ If there is more than one child in the household, the parents remaining income is divided equally among them. If the child has any earned or unearned income of his/her own, exclusions are applied and this income is added to the income deemed from the parents.
} 
than the child's countable income. The payment is the difference between the total (potential) SSI benefit for the state and the child's countable income. Because one half of earned income is deducted in the computation of countable income (after an initial \$65 deduction), SSI participation imposes a 50\% marginal tax rate on earned income beyond a certain level. This presents an important difference with the AFDC program, which imposes a 100\% marginal tax rate on earned income ( $66 \%$ for the first four months).

\section{Eligibility and payment determination in AFDC program}

For AFDC, current rules determining eligibility and the payment amount differ somewhat depending on how long a family has been in the program. The most common case is presented in which the family has been receiving AFDC payments for over 12 months (around $34 \%$ of recipients have been on AFDC for less than 12 months). First, gross income is computed which typically includes the earned and unearned income of the parent(s) of a dependent child. Second, a $\$ 90$ work expense disregard is applied if the parent has earned income, as well as disregards for child care expenses in order to obtain the family's countable income. Each state sets a maximum grant amount that varies by family size. The family is eligible for a payment if the maximum grant is greater than countable income. The amount of the payment is the difference between the maximum grant for the family and countable income. 


\section{References}

Byerly, Edwin R., Kevin Deardorff, (1995). National and state population estimates: 1990 to 1994. U.S. Bureau of the Census, Current Population Reports, P25-1127, U.S.

Washington, D.C.: Government Printing Office

Byerly, Edwin R., (1993). State population estimates by age and sex: 1980 to 1992. U.S. Bureau of the Census, Current Population Reports, P25-1106, Washington, D.C.: U.S. Government Printing Office

Glied, S., C.W. Hoven, R. Moore, A.B. Garrett, M. Rubio-Stipec, P. Leaf, S. Goodman. D. Regier, (1997). Children's access to mental health care: does insurance matter?". Health Affairs, January-February 1997, Vol. 16, No.1.

Hannsgen, G.P., S.H. Sandell, "Deeming Rules and the Increase in the Number of Children with Disabilities Receiving SSI: Evaluating the Effects of a Regulatory Change". Social Security Bulletin, Vol. 59, No. 1.

Kearney, J.R., Grundmann, H.F., Gallicchio, S.J. (1994). "The influence of Social Security benefits and SSI payments on the poverty status of children." Social Security Bulletin. Vol. 57, No. 2, Summer 1994.

Kennedy, L. (1993). "Children receiving SSI payments, December 1992." Social Security Bulletin. Vol. 56, No.2, Summer 1993.

Rupp, K., D. Stapleton (1995). "Determinants of the growth in the Social Security Administration's disability programs--an overview." Social Security Bulletin. v58, n4 (Winter), pp.43-70.

Social Security Administration (various years). Office of Supplemental Security Income, State Assistance Programs for SSI Recipients.

Social Security Administration. (1995, October). Supplemental Security Income for Children with Disabilities (Report to Congress of the National Commission on Childhood Disability). Washington, DC: Author.

U.S. Congress, House Committee on Ways and Means. Overview of Entitlement Programs ("Green Book", various years). Washington DC: U.S. Government Printing Office.

U.S. General Accounting Office. (1995, July). Supplemental Security Income: Growth and Changes in Recipient Population: Call For Reexamining Program (GAO/HEHS 95-137). Washington, DC: Author. 
Figure 1. The number of child SSI participants (1985-1995)

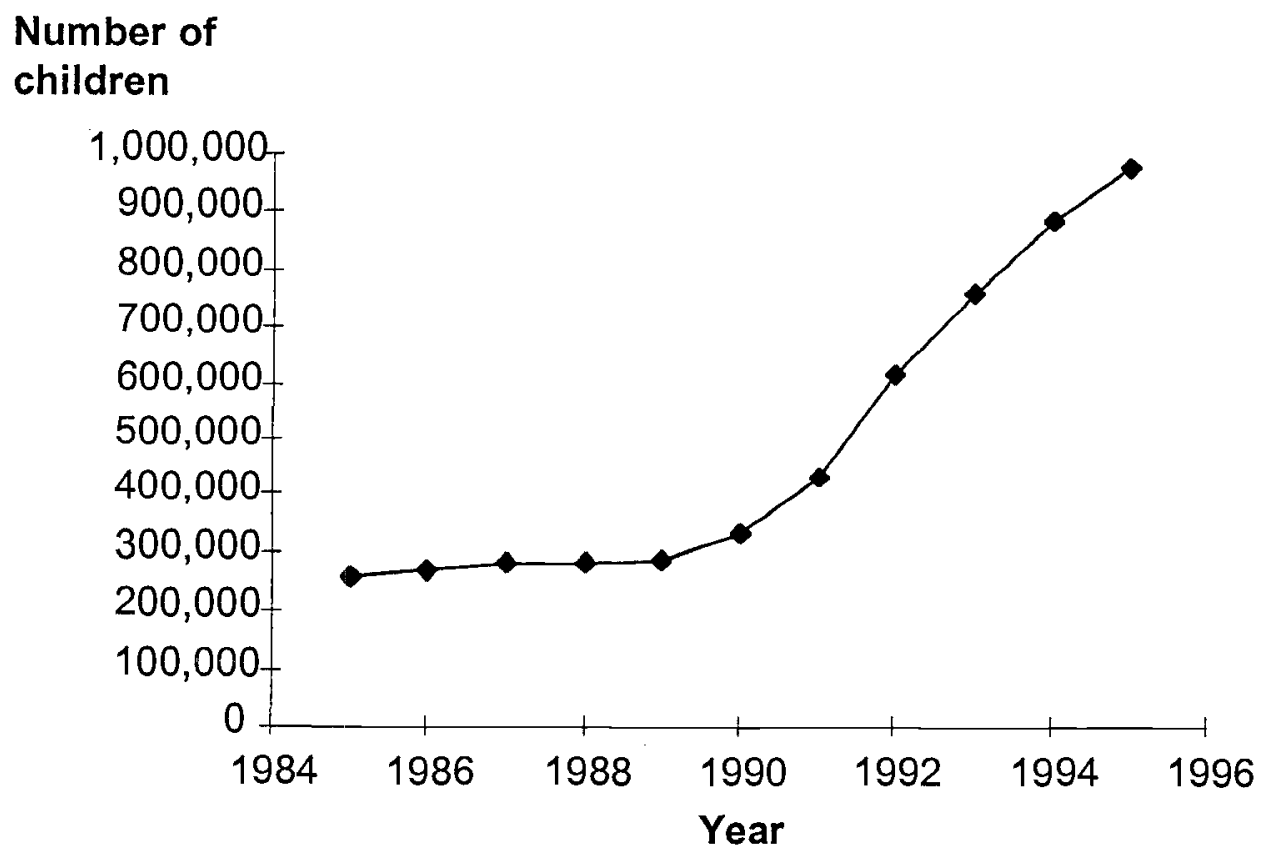


Table 1. Summary of the effects of Zebley on Child SSI and AFDC participation under three hypotheses

\begin{tabular}{|c|c|c|c|c|}
\hline Hypothesis: & In states with... & $\begin{array}{l}\text { Child SSI } \\
\text { participation }\end{array}$ & $\begin{array}{l}\text { Child AFDC } \\
\text { participation }\end{array}$ & $\begin{array}{l}\text { Total child } \\
\text { program } \\
\text { participation }\end{array}$ \\
\hline $\begin{array}{l}\text { Everyone switches to } \\
\text { SSI who is eligible } \\
\text { (i.e. demonstrating } \\
\text { impairment is costless) }\end{array}$ & $\begin{array}{l}\text { higher maximum } \\
\text { AFDC payments } \\
\text { higher SSI } \\
\text { supplementation } \\
\text { payments }\end{array}$ & $\begin{array}{l}\text { is not affected } \\
\text { increases more }\end{array}$ & is not affected & $\begin{array}{l}\text { increases less } \\
\text { increases more }\end{array}$ \\
\hline $\begin{array}{l}\text { SSI participation } \\
\text { depends on benefit gap } \\
\text { (i.e. demonstrating } \\
\text { impairment is costly) }\end{array}$ & $\begin{array}{l}\text { higher maximum } \\
\text { AFDC payments } \\
\text { higher SSI } \\
\text { supplementation } \\
\text { payments }\end{array}$ & increases more & $\begin{array}{l}\text { is ambiguously } \\
\text { affected } \\
\text { decreases more }\end{array}$ & $\begin{array}{l}\text { increases less } \\
\text { increases more }\end{array}$ \\
\hline $\begin{array}{l}\text { SSI participation } \\
\text { depends on } \\
\text { information obtained } \\
\text { in welfare offices }\end{array}$ & $\begin{array}{l}\text { higher maximum } \\
\text { AFDC payments } \\
\text { higher SSI } \\
\text { supplementation } \\
\text { payments }\end{array}$ & increases more & is not affected & $\begin{array}{l}\text { is ambiguously } \\
\text { affected } \\
\text { increases more }\end{array}$ \\
\hline
\end{tabular}


Table 2. Data descriptions and sources

\begin{tabular}{|c|c|}
\hline Variable & Description \\
\hline $\begin{array}{l}\text { Child SSI } \\
\text { Participation }\end{array}$ & $\begin{array}{l}\text { Number of children receiving federally- } \\
\text { administered SSI payments in } \\
\text { December of year. Includes some full- } \\
\text { time students age } 18-21 \text {. Reported by } \\
\text { blind/disabled status. }\end{array}$ \\
\hline
\end{tabular}

Source

Adult SSI
Participation

Number of adults receiving SSI

payments in December of year.

Includes the majority of persons age

18-21 receiving SSI.

State SSI

Supplementation (deflated)

Maximum payment to child living with parents. This value is set to zero if the state has no program or does not make supplemental payments to children in families.

AFDC Adult and Child Recipients

Monthly average adult and child AFDC recipients in calendar year.

Social Security Bulletin Annual Statistical Supplement (various years)

AFDC Maximum Payment (deflated)

Maximum AFDC payment to family of three consisting of one eligible parent and two eligible children

State AFDC share

$100 \%$ - Federal Medical Assistance Percentage.

Characteristics of State AFDC Programs (various years)

State unemployment rate

Annual average state unemployment

Child poverty rate rate (seasonally adjusted)

Poverty rate of children ages 5-17 (consistently defined over period)

Income per capita Personal income per capita

Child population Census estimates of U.S. population age $0-17$

State Assistance Programs for SSI Recipients (various years)

Social Security Bulletin Annual Statistical Supplement (various years)

Social Security Bulletin Annual
Statical Supplement (various years)

(various years)

Characteristics of State AFDC Programs (various years)

Bureau of Labor Statistics

U.S. Bureau of the Census, Current Population Reports

U.S. Bureau of Economic Analysis, Survey of Current Business

Current Population Reports (Byerly, 1993; Byerly and Deardorff, 1995), U.S. Bureau of the Census 
Dollar deflator
Statistical Abstract of the United States (1995) 
Table 3. Summary statistics for 1989 and 1992

\begin{tabular}{lll}
\hline Year & 1989 & 1992 \\
\hline
\end{tabular}

U.S. totals

Population under age 18

$63,453,000$

$66,162,391$

Child SSI recipients

296,298

623,731

Blind Child SSI recipients

7,910

9,362

Adult SSI recipients

$4,295,787$

$4,941,829$

States with SSI

19

19

supplementation for children

Child AFDC recipients

$7,287,257$

$9,164,843$

Adult AFDC recipients

$3,501,018$

$4,388,216$

U.S. state averages

Unemployment Rate

5.2

6.9

Child SSI participation

$0.452 \%$

$0.922 \%$

Child AFDC participation

$10.09 \%$

$12.31 \%$

State SSI supplementation

$\$ 35.26^{*}$

$\$ 30.85^{*}$

for children (for states with

supplementation for

children)

Maximum AFDC grant for

$\$ 303.68^{*}$

$\$ 281.47^{*}$

family of three

* CPI deflated. 
Table 4a. Child SSI participation before and after the Sullivan v. Zebley decision

\begin{tabular}{l|ccl} 
& Low AFDC & High AFDC & Difference \\
\hline Before Zebley (1989) & 0.542 & 0.350 & $-0.192^{* *}$ \\
& $(0.039)$ & $(0.022)$ & $(0.045)$ \\
After Zebley (1992) & 1.148 & 0.676 & $-0.472^{* *}$ \\
& $(0.102)$ & $(0.049)$ & $(0.114)$ \\
Difference & $0.606^{* *}$ & $0.326^{* *}$ & \\
& $(0.110)$ & $(0.054)$ & \\
Difference in & & & $-0.281^{* *}$ \\
Difference & & & $(0.122)$ \\
** significant at 5\%. * significant at 10\%. & &
\end{tabular}

Table 4b. Adult SSI participation before and after the Sullivan v. Zebley decision

\begin{tabular}{l|ccl} 
& Low AFDC & High AFDC & Difference \\
\hline Before Zebley (1989) & 2.532 & 1.656 & $-0.876^{* *}$ \\
& $(0.242)$ & $(0.135)$ & $(0.277)$ \\
After Zebley (1992) & 2.742 & 1.885 & $-0.857^{* *}$ \\
& $(0.239)$ & $(0.148)$ & $(0.281)$ \\
Difference & 0.210 & 0.229 & \\
& $(0.340)$ & $(0.200)$ & \\
Difference in & & & 0.019 \\
Difference & & & $0.395)$ \\
** significant at 5\%. * significant at 10\%. & & \\
. &
\end{tabular}


Table 5a. The effect of Sullivan $v$. Zebley and state program characteristics on child program participation: base model

\begin{tabular}{|c|c|c|c|}
\hline $\mathrm{N}=300$ & $\begin{array}{c}\text { SSI } \\
\text { participation } \\
\text { rate }\end{array}$ & $\begin{array}{c}\text { AFDC } \\
\text { participation } \\
\text { rate }\end{array}$ & $\begin{array}{l}\text { Total program } \\
\text { participation } \\
\text { rate }\end{array}$ \\
\hline \multirow[t]{2}{*}{ Year } & $0.051^{* *}$ & $0.723^{* *}$ & $0.775^{* *}$ \\
\hline & $(0.017)$ & $(0.095)$ & $(0.095)$ \\
\hline \multirow[t]{2}{*}{ Zebley } & $1.18^{* *}$ & 0.263 & $1.44 * *$ \\
\hline & $(0.125)$ & $(0.534)$ & $(0.504)$ \\
\hline \multirow[t]{2}{*}{ AFDC maximum grant } & $-0.0016^{* *}$ & $0.020^{* *}$ & $0.019^{* *}$ \\
\hline & $(0.00067)$ & $(0.0040)$ & $(0.0040)$ \\
\hline \multirow[t]{2}{*}{ AFDC maximum grant * Zebley } & $-0.0020^{* *}$ & 0.00004 & $-0.0020^{*}$ \\
\hline & $(0.00025)$ & $(0.0011)$ & $(0.0011)$ \\
\hline \multirow[t]{2}{*}{ State Supplementation } & $0.0091^{* *}$ & 0.016 & 0.025 \\
\hline & $(0.0032)$ & $(0.018)$ & $(0.019)$ \\
\hline \multirow[t]{2}{*}{ State Supplementation * Zebley } & $0.0052^{* *}$ & -0.0081 & -0.0028 \\
\hline & $(0.0012)$ & $(0.0079)$ & $(0.0081)$ \\
\hline \multirow[t]{2}{*}{ State AFDC share } & $0.036^{* *}$ & 0.013 & 0.049 \\
\hline & $(0.0056)$ & $(0.035)$ & $(0.034)$ \\
\hline \multirow[t]{2}{*}{ State AFDC share * Zebley } & $-0.0057^{*}$ & -0.0032 & -0.0089 \\
\hline & $(0.0032)$ & $(0.012)$ & $(0.013)$ \\
\hline \multirow[t]{2}{*}{ Unemployment rate } & $-0.071 * *$ & $0.327^{* *}$ & $0.257^{* *}$ \\
\hline & $(0.014)$ & $(0.073)$ & $(0.072)$ \\
\hline \multirow[t]{2}{*}{ Poverty rate } & 0.0047 & $0.051^{* *}$ & $0.055^{* *}$ \\
\hline & $(0.0038)$ & $(0.020)$ & $(0.019)$ \\
\hline \multirow[t]{2}{*}{ Income per capita } & -0.000004 & $-0.0018^{* *}$ & $-0.0018 * *$ \\
\hline & $(0.00004)$ & $(0.00024)$ & $(0.00024)$ \\
\hline Within- $\mathrm{R}^{2}$ & 0.88 & 0.72 & 0.81 \\
\hline
\end{tabular}

${ }^{* * *}$ significant at $5 \% .{ }^{*}$ significant at $10 \%$. OLS fixed-effects estimates. Huber-White robust standard errors are in parentheses. Regressions include a constant term. 
Table 5b. The effect of Sullivan $v$. Zebley and state program characteristics on child program participation: adding state-specific trends

\begin{tabular}{|c|c|c|c|}
\hline$N=300$ & $\begin{array}{c}\text { SSI } \\
\text { participation } \\
\text { rate }\end{array}$ & $\begin{array}{c}\text { AFDC } \\
\text { participation } \\
\text { rate }\end{array}$ & $\begin{array}{c}\text { Total program } \\
\text { participation } \\
\text { rate } \\
\end{array}$ \\
\hline \multirow[t]{2}{*}{ Zebley } & $0.610 * *$ & 0.914 & $1.52 * *$ \\
\hline & $(0.206)$ & $(0.741)$ & $(0.680)$ \\
\hline \multirow[t]{2}{*}{ AFDC maximum grant } & -0.00077 & 0.0028 & 0.0020 \\
\hline & $(0.00099)$ & $(0.0033)$ & $(0.0035)$ \\
\hline \multirow[t]{2}{*}{ AFDC maximum grant * Zebley } & $-0.0012 * *$ & -0.0014 & -0.0026 \\
\hline & $(0.00045)$ & $(0.0020)$ & $(0.0020)$ \\
\hline \multirow[t]{2}{*}{ State Supplementation } & -0.0044 & -0.014 & -0.018 \\
\hline & $(0.0047)$ & $(0.026)$ & $(0.027)$ \\
\hline \multirow[t]{2}{*}{ State Supplementation * Zebley } & 0.0017 & -0.0010 & 0.00069 \\
\hline & $(0.0015)$ & $(0.0098)$ & $(0.010)$ \\
\hline \multirow[t]{2}{*}{ State AFDC share } & $0.038 * *$ & $-0.104^{* *}$ & $-0.066^{* *}$ \\
\hline & $(0.0074)$ & $(0.029)$ & $(0.028)$ \\
\hline \multirow{2}{*}{ State AFDC share * Zebley } & 0.00055 & 0.015 & 0.015 \\
\hline & $(0.0055)$ & $(0.021)$ & $(0.021)$ \\
\hline \multirow[t]{2}{*}{ Unemployment rate } & $-0.026^{*}$ & $0.160^{* *}$ & $0.134 * *$ \\
\hline & $(0.013)$ & $(0.058)$ & $(0.057)$ \\
\hline \multirow[t]{2}{*}{ Poverty rate } & 0.0026 & 0.019 & $0.021 *$ \\
\hline & $(0.0025)$ & $(0.012)$ & $(0.011)$ \\
\hline \multirow[t]{2}{*}{ Income per capita } & 0.00002 & $-0.0011 * *$ & $-0.0011 * *$ \\
\hline & $(0.00005)$ & $(0.00029)$ & $(0.00028)$ \\
\hline Within- $\mathrm{R}^{2}$ & 0.97 & 0.94 & 0.96 \\
\hline
\end{tabular}

Regression also includes a continuous time variable, 49 state-specific trend terms, and a constant. ** significant at 5\%. * significant at $10 \%$. OLS fixed-effects estimates. Huber-White robust standard errors are in parentheses. 
Table 5c. The effect of Sullivan $v$. Zebley and state program characteristics on child program participation: adding adult SSI participation

\begin{tabular}{|c|c|c|c|}
\hline $\mathrm{N}=300$ & $\begin{array}{c}\text { SSI } \\
\text { participation } \\
\text { rate }\end{array}$ & $\begin{array}{c}\text { AFDC } \\
\text { participation } \\
\text { rate }\end{array}$ & $\begin{array}{l}\text { Total program } \\
\text { participation } \\
\text { rate }\end{array}$ \\
\hline \multirow[t]{2}{*}{ Year } & 0.017 & $0.646^{* *}$ & $0.663^{* *}$ \\
\hline & $(0.015)$ & $(0.092)$ & $(0.088)$ \\
\hline \multirow[t]{2}{*}{ Zebley } & 0.128 & 0.052 & 0.180 \\
\hline & $(0.109)$ & $(0.640)$ & $(0.615)$ \\
\hline \multirow[t]{2}{*}{ AFDC maximum grant } & $-0.0019^{* *}$ & $0.021 * *$ & $0.019 * *$ \\
\hline & $(0.00060)$ & $(0.0037)$ & $(0.0035)$ \\
\hline \multirow[t]{2}{*}{ AFDC maximum grant * Zebley } & $-0.0011 * *$ & 0.00012 & -0.00096 \\
\hline & $(0.00020)$ & $(0.0011)$ & $(0.0011)$ \\
\hline \multirow[t]{2}{*}{ State Supplementation } & $0.0078 * *$ & 0.013 & 0.021 \\
\hline & $(0.0029)$ & $(0.016)$ & $(0.015)$ \\
\hline \multirow[t]{2}{*}{ State Supplementation * Zebley } & 0.0014 & -0.011 & -0.0098 \\
\hline & $(0.0010)$ & $(0.0078)$ & $(0.0074)$ \\
\hline \multirow[t]{2}{*}{ State AFDC share } & $0.014 * *$ & 0.010 & 0.025 \\
\hline & $(0.0046)$ & $(0.034)$ & $(0.033)$ \\
\hline \multirow[t]{2}{*}{ State AFDC share * Zebley } & 0.0034 & -0.0041 & -0.00071 \\
\hline & $(0.0022)$ & $(0.013)$ & $(0.012)$ \\
\hline \multirow[t]{2}{*}{ Unemployment rate } & $-0.070 * *$ & $0.346^{* *}$ & $0.276^{* *}$ \\
\hline & $(0.011)$ & $(0.069)$ & $(0.066)$ \\
\hline \multirow[t]{2}{*}{ Poverty rate } & 0.0025 & $0.040^{* *}$ & $0.042 * *$ \\
\hline & $(0.0030)$ & $(0.019)$ & $(0.018)$ \\
\hline \multirow[t]{2}{*}{ Income per capita } & 0.00006 & $-0.0018 * *$ & $-0.0017^{* *}$ \\
\hline & $(0.00003)$ & $(0.00024)$ & $(0.00023)$ \\
\hline \multirow[t]{2}{*}{ Adult SSI participation rate } & 0.073 & $1.57^{* *}$ & $1.65^{* *}$ \\
\hline & $(0.099)$ & $(0.542)$ & $(0.504)$ \\
\hline \multirow[t]{2}{*}{ Adult SSI participation rate * Zebley } & $0.230 * *$ & 0.059 & $0.289 * *$ \\
\hline & $(0.026)$ & $(0.124)$ & $(0.112)$ \\
\hline Within- $\mathrm{R}^{2}$ & 0.91 & 0.96 & 0.83 \\
\hline
\end{tabular}

** significant at $5 \%$. * significant at $10 \%$. OLS fixed-effects estimates. Huber-White robust standard errors are in parentheses. Regressions include a constant term. 
Table 6 The effect of Zebley on the federal composition of child cash benefits.

\begin{tabular}{|c|c|c|c|c|c|c|}
\hline Year & $\begin{array}{c}\text { Quintile of } \\
\text { maximum } \\
\text { AFDC } \\
\text { grant } \\
\text { (5=highest) }\end{array}$ & $\begin{array}{l}\text { Number of } \\
\text { children in } \\
\text { quintile receiving } \\
\text { SSI or AFDC } \\
\text { payments } \\
\text { (1000's) }\end{array}$ & $\begin{array}{l}\text { Average } \\
\text { monthly cash } \\
\text { payments to } \\
\text { children }(\$)\end{array}$ & $\begin{array}{l}\text { Average } \\
\text { Federally- } \\
\text { financed } \\
\text { monthly cash } \\
\text { payments to } \\
\text { children }(\$)\end{array}$ & $\begin{array}{c}\text { Average } \\
\text { Federal } \\
\text { share }(\%)\end{array}$ & $\begin{array}{l}\text { Percent } \\
\text { Change }\end{array}$ \\
\hline \multirow[t]{5}{*}{1989} & 1 & 1,464 & 93.6 & 71.1 & 75.9 & \\
\hline & 2 & 1,347 & 131.3 & 85.7 & 65.3 & \\
\hline & 3 & 854 & 150.5 & 85.0 & 56.5 & \\
\hline & 4 & 1,440 & 190.9 & 113.3 & 59.3 & \\
\hline & 5 & 2,480 & 248.1 & 131.1 & 52.9 & \\
\hline \multirow[t]{5}{*}{1992} & 1 & 1,918 & 104.2 & 84.9 & 81.5 & 7.4 \\
\hline & 2 & 1,947 & 132.2 & 91.7 & 69.3 & 6.2 \\
\hline & 3 & 1,037 & 150.5 & 92.9 & 61.7 & 9.2 \\
\hline & 4 & 1,057 & 177.1 & 112.7 & 63.7 & 7.3 \\
\hline & 5 & 3,245 & 231.8 & 126.6 & 54.6 & 3.4 \\
\hline
\end{tabular}


Table 7. The effect of Sullivan $v$. Zebley on the employment of unmarried women with a high school education or less: OLS fixed effects estimates

\begin{tabular}{lll}
\hline $\mathrm{N}=300$ & \multicolumn{2}{c}{$\begin{array}{c}\text { Dependent variable: State } \\
\text { employment rate }\end{array}$} \\
& $\begin{array}{c}\text { of unmarried women with a high } \\
\text { school education or less }\end{array}$ \\
\hline Year & $1.11^{* *}$ & $0.893^{*}$ \\
Zebley & $(0.495)$ & $(0.493)$ \\
& -2.59 & -2.93 \\
AFDC maximum grant & $(2.70)$ & $(2.67)$ \\
AFDC maximum grant * Zebley & -0.051 & $-0.058^{*}$ \\
State Supplementation & $(0.034)$ & $(0.033)$ \\
State Supplementation * Zebley & $-0.022^{* *}$ & $-0.013^{* *}$ \\
& $(0.0069)$ & $(0.0067)$ \\
Male unemployment rate & -0.061 & -0.018 \\
Within-R & $(0.119)$ & $(0.126)$ \\
& -0.058 & -0.029 \\
& $(0.048)$ & $(0.050)$ \\
& -- & $-1.52^{* *}$ \\
\hline
\end{tabular}

** significant at 5\%. ${ }^{*}$ significant at $10 \%$. OLS fixed-effects estimates. Huber-White robust standard errors are reported in parentheses. Regressions include a constant term. 